S A Journal of Industrial Engineering, vol. 1, No 2, December 1987, pp. 5-

\title{
OPMERKINGS RAKENDE DIE GEBRUIK VAN STANDAARDURE IN
}

\section{VERVAARDIGINGSONDERNEMINGS}

\author{
Dr ABRE PIENAAR Pr Ing \\ Raadgewende Bedryfsingenieur \\ Midrand
}

\section{ABSTRACT}

Manufacturing companies use standard hours as a common unit of measurement to ascertain the impact of different schedules in a changing mix of products. This study discusses the nature of standard hours as an instrument for quantifying capacity and the applications of standard hours in manufacturing companies.

\section{OPSOMMING}

Standaardure word dikwe Ts gebruik in vervaardigingsondernemings waar die mengsel van produkte sodanig verander dat 'n gemeenskaplike maatstaf benodig word om die impak van verskillende skedules te bepaal. In hierdie werkstuk word enkele opmerkings gemaak aangaande die aard van standaardure as kwantitatiewe meetinstrument en ook ' $n$ uiteensetting gegee van die gebruike daarvan in vervaardigingsondernemings. 


\section{INLEIDING}

Die bestuursproblematiek van 'n vervaardigingsonderneming is al beskryf as fundamenteel die taak van skedulering van materiaal en kapasiteit (Wight [ 1$]$ ) en dit vereis dat beide hierdie begrippe gekwantifiseer word. Kwantifisering van materiaal is relatief eenvoudig en voor-die-hand-liggend maar in die geval van kapasiteit bestaan verskeie tegnieke en ook soms onduidelikheid. In hierdie werkstuk word standaardure as 'n meganisme vir die kwantifisering van kapasiteit bespreek.

\section{KWANTIFISERING VAN KAPASITEIT}

Die term "kapasiteit" verwys na die eindige vermoens van vervaardigingsondernemings in terme van die volume produkte wat per tydperiode geprosesseer kan word. Gewoonlik bestaan daar verskillende soorte kapasiteitbeperkings in dieselfde onderneming, elk waarvan 'n submaksimum op die prosesseringsvermot per periode plaas. Hierdie nie-uitruilbare kapasiteitbeperkings word in werksentra saamgegroepeer en kan basies na arbeidbeperkings of masjienvermokbeperkings of selfs 'n kombinasie van die twee herlei word.

Skedulering van kapasiteit impliseer dat daar vir elke werksentrum 'n sogenaamde kapasiteitvergelyking opgestel moet word wat die vraag en aanbodkante van kapasiteit in die werksentrum vergelyk. Die randvoorwaarde vir geldige skedulering is natuurlik dat:

$$
\text { Vraag na kapasiteit } \leqslant \text { Aanbod van kapasiteit }
$$

vir die betrokke werksentrum in die betrokke periode.

Vervaardigingsprosesse wat in enkele produk (byvoorbeeld prosesnywerhede soos chemiese aanlegte) of ' $n$ mengsel produkte waarvan die kapasiteitsimplikasies vir praktiese doeleindes dieselfde is (byvoorbeeld ' $n$ monteerlyn vir verskillende modelle van dieselfde basiese item), produseer, druk gewoonlik kapasiteitsbeperkings in terme van produkeenhede uit. (Daar sal byvoorbeeld gesê word 'n aanleg vir die produksie van 'n soort kunsmis kan 12000 ton van die kunsmis per dag produseer en 'n monteerlyn vir ' $n$ sekere soort motor kan 75 motors per dag produseer.)

In taakwerkwinkels en ander vervaardigingsprosesse waar die produkte verskillende hoeveethede van die beskikbare kapasiteit vereis, is die beperkings op die uitsetvermoens van 'n werksentrum afhanklik van die spesifieke mengsel produkte wat in ' $n$, bepaalde periode geskeduleer word. 'n Gemeenskaplike maatstaf vir die kwantifisering van die totale kapasiteit wat vereis word in die periode word in hierdie geval benodig en standaardure is die thees algemene eenheid wat gebruik word.

'n Standaarduur is 'n eenheid van meting van kapasiteit, hetsy of kapasiteit na arbeidsbeperkings of masjienbeperkings of ' $n$ kombinasie van die die twee in enige spesifieke werksentrum verwys. 
Aangesien al die verskillende produksiefaktore soos direkte arbeid, kapitaltoerusting, bedryfsomgewing en die indirekte ondersteuning van toesighouding en staffunksies 'n rol speel by die bepaling van die kapasiteit van ' $n$ werksentrum, volg dit dat standaardure die matstaf is van al die produksievermoens benodig om 'n gegewe produk in 'n gegewe werksentrum te verwerk.

Dit is ook ter sake om op te merk dat standaardure ' $n$ kunsmatige eenheid van meting is en gebruik word om die relatiewe impak van verskillende produkte op dieselfde werksentrum in dieselfde periode te bepaa 1 .

\section{STANDAARDURE EN ARBEIDSURE}

Bostaande uiteensetting moet gelees word in kontras met die tyd benodig deur 'n direkte werker om 'n taak te verrig - 'n verwante begrip waarvoor die term "arbeidsure" in hierdie werkstuk gebruik word.

'n Kritiese insig is dat standaardure en arbeidsure twee verskillende eenhede van meting is:

* Standaardure is, soos hierbo uiteengesit, die eenheid van meting van die gemiddelde verbruik van produksiefaktore oftewel die maatstaf van kapasiteit hetsy dit arbeid, masjienkapasiteit, 'n kombinasie van die twee of enige ander ter sake produksiefaktor is.

* Arbeidsure is 'n maatstaf van die verloop van chronologiese tyd deur ' $n$ spesifieke werker aan' $n$ spesifieke taak gespandeer en meet dus slegs direkte arbeid.

In arbeidsintensiewe ondernemings word die twee eenhede van meting dikwels dieselfde geag aangesien chronologiese tydsverloop - die arbeidsure - die pasaangewende produksiefaktor is en die twee benaderings prakties gesproke dieselfde resultaat lewer.

Waar dieselde werker meer as een taak tergelykertyd verrig of die tempo deur masjienvermoel bepaal word, is onderskeid egter noodsaaklik. Die rede hiervoor is nie onmiddellik duidelik wanneer konstante produksie gehandhaaf word nie, aangesien, met behulp van die metodes van tydstudie, die uitset per arbeidsuur direk meetbaar is.

Aangesien in laasgenoemde geval die produksie-uitset per arbeidsuur benodig egter NIE lineêr toe- of afneem nie, in die praktyk dikwels nie eers vir beperkte veranderings nie, is dit nie moontlik om die resultate van die tydstudie te ekstra- of intrapoleer ten einde die arbeidskomponent vir enige nuwe uitsetvlak te bereken nie. $0 \mathrm{~m}$ arbeidsure te bepaal, moet ' $n$ nuwe tydstudie gedoen word.

Standaardure, gebaseer op gedemonstreerde resultate, is egter wel ekstrapoleerbaar. vir beperkte kurwes. 


\section{MEETMETODES}

Tydstudie is een van die mees algemene tegnieke vir die bepaling van die hoeveelheid direkte arbeid benodig om 'n taak te verrig. Aanvaarbare vlakke van akkuraatheid word bereik deur die taak in klein, maklik meetbare taakelemente te verdee1, die tydsduur van elk te meet, en deur gebruik te maak van toelatings die totale tydsduur van die taak te sintetiseer. Arbeidsure word dan ook normaalweg in vervaardigingsonderneming met behulp van tydstudie en verwante tegnieke gemeet.

Met die bepaling van standaardure egter moet die interaksie tussen arbeid en die ander produksiefaktore wat uitset beperk, in ag geneem word. 'n Baie fyn verdeling in taakelemente voordat gemeet word, is geneig om in die praktyk hierdie interaksie te elimineer. Die gevolg is dat standaardure gewoonlik in relatief groot bewerkingstappe uitgedruk word en dat dit NIE ' $n$ grootheid is wat op 'n teoretiese grondslag bereken word nie (alhoewel skattings wel gemaak en gebruik kan word vir voorlopige skedulering, kapasiteitsbeplanning en kwotasies). Die enigste realistiese metode vir die bepaling van standaardure is deur die gedemonstreerde standaardure vir die produk in die werksentrum te bepaal.

In praktiese terme beteken dit dat standaardure bepaal word deur die uitset van ' $n$ werksentrum oor 'n redelike aantal siklusse te monitor en die gemiddelde tydsverloop te bepaal wat die spesifieke produk ter sprake neem om geprosesseer te word terwyl. die werksentrum ook aan ander produkte werk. Ten einde die probleem van dubbelallokering van tyd aan verskillende produkte te oorkom, is dit belangrik om terselfdertyd die aanbodkant van die kapasiteitvergelyking, die kapasiteit beskikbaar in die werksentrum, te bepaal en dit is natuurlik slegs die som van die standaardure van al die produkte in die periode geproduseer mits die werksenrtrum vol belaai was.

Aangesien standaardure ' $n$ kunsmatige eenheid is wat relatiewe impak bepaal, volg dit ook geredelik dat die akkuraatheid van die standaardure vir in bepaalde produk NIE bepaal word deur die ooreensteming met die chronologiese tydsverloop in werklike produksie nie maar deur die getrouheid van weergawe van die relatiewe tydsverloop in vergelyking met al die ander produkte wat in diesetfde periode in die werksentrum geproduseer word.

\section{GEBRUIK YAN STANDAARDURE}

Nadat kwantifisering voltooi is, word die standaardure gebruik om die volgende doelwitte te bereik:

\subsection{Skedulering}

In produksiebeplanningstelsels word die standaardure wat benodig word in opeenvolgende bewerkings om 'n produk te produseer, gebruik on die detail skedulering van die taak mee uit te voer. 
Gestel die roetewyser vir die vervaardiging van item $x$ en die werksentrumdata vir hierdie onderneming, toon die volgende inligting:

$\begin{array}{lll}\text { Operasie } 10 & \text { Werksentrum A } & 2 \text { uur/item } \\ \text { Operasie } 20 & \text { Werksentrum B } & 1 \text { uur/item }\end{array}$

$\begin{array}{ll}\text { Kapasiteit van werksentrum A: } & 20 \mathrm{uur} / \mathrm{dag} \\ \text { Kapasiteit van werksentrum B: } & 10 \mathrm{uur} / \mathrm{dag}\end{array}$

Die woord "uur" in bostaande data verwys telkens na standaardure. Indien ' $n$ lot van 40 van item $X$ vervaardig moet word, volg die volgende berekening geredelik:

Skedule in standaardure:

$\begin{array}{ll}\text { Operasie } 10 & 80 \text { uur } \\ \text { Operasie } 20 & 40 \text { uur }\end{array}$

Skedule in werksdae:

$\begin{array}{ll}\text { Operasie } 10 & 4 \text { dae } \\ \text { Operasie } 20 & 4 \text { dae }\end{array}$

Gestel een dag word in alle skedules toegelaat vir materiaaluitreiking met die aanvang van 'n taak en dat hierdie taak voltooi moet wees op Vrydag die sewentiende. Die detail skedulering van die taak word dan soos volg uiteengesit:

Reik materiaal uit vir 40 van $X$ Dinsdag die sewende

Begin Operasie 10

Woensdag die agste

Voltooi Operasie 10

Maandag die dertiende

Begin Operasie 20

Dinsdag dié veertiende

Voltooi Operasie 20

Vrydag die sewentiende 


\subsection{Kapasiteitbeplanning}

Die standaardure bereken word nou gebruik om die relatiewe kapasiteitbelading van ' $n$ werksentrum te bestuur deur die totale kapasiteit vereis deur verskillende produksieskedules te vergelyk met die beskikbare kapasiteit vir 'n gegewe periode.

Uit bostaande voorbeeld is dit duidelik dat 40 standaardure van werksentrum $B$ in die derde week van die maand vereis word vir die produksie van 40 van $X$. Hierdie is 'n maatstaf van kapasiteit benodig, die vraagkant van die kapasiteitsvergelyking.

Gestel ' $n$ verdere taak, naamlik die produksie van 10 eenhede van $Y$, word geskeduleer op werksentrum $B$ in dieselfde week. Indien hierdie tweede taak 15 standaardure vereis, is die totale vraag na kapasiteit in hierdie werksentrum in hierdie week 55 standaardure. Aangesien slegs 50 standaardure normalweg beskikbaar is, word bestuursaksie (byvoorbeeld skedulering van oortyd) benodig om die voorsieningskant van die kapasiteitsvergelyking te balanseer met die vraagkant (verwys na randvoorwaarde (1)).

\subsection{Kosteberekening}

Kosteberekening van die nie-materiaalgedeelte van ' $n$ produk se direkte eenheidskoste word gedoen deur die koste van standaardure vir die verskillende werksentra betrokke by die vervaardiging van die produk, te bereken.

Gestel die standaardkoste per werksentrum in die huidige voorbeeld is soos volg:

$$
\begin{array}{ll}
\text { Standaardtarief vir werksentrum A: } & \text { R30/uur } \\
\text { Standaardtarief vir werksentrum B: } & \text { R50/uur }
\end{array}
$$

Vir produk $X$ is hierdie koste-element dus $R 110$ en dit word by die materiaalkoste getel om die direkte koste van $X$ te bepal.

\section{GEVOLGTREKKINGS}

Kwantifisering van kapasiteit in vervaardigingsprosesse wat verskillende produkte produseer word gewoonlik in terme van standaardure gedoen. Hierdie standaardure verskaf brondata vir taakskedulering, kapasiteitsbestuur en kosteberekening.

In werksentra waar die arbeidskomponent van kapasiteit nie noodwendig die pas aangee by die bepaling van uitsettempo nie, is dit belangrik om die verskil tussen standaardure wat die interaksie van al die produksiefaktore meet en arbeidsure wat slegs chronologiese verloop van arbeidstyd meet, in ag te neem wanneer kwantifisering van kapasiteit plaasvind. 


\section{VERWYSINGS}

[1] Wight $0 \mathrm{~W}, 1981$, "MRP II, Unlocking America's productivity potential", $0 \mathrm{~W}$ Wight Limited Publications, Inc, Williston VT, 555 pages. 